DOI:

UDC 621.926.001.66

O. Panchenko, Ph.D. in Tech. Sc., Associate Professor, panchenko.o.v@nmu.one National Technical University "Dnipro Polytechnic", Dnipro

\title{
SUBSTANTIATION OF THE ALGORITHM FOR MODELING OF THE JAW CRUSHER MECHANISM WITH A SIMPLE MOVEMENT OF THE JAW
}

The actual scientific problem is solved in the work, which consists in substantiation of the algorithm of modeling of the jaw crusher mechanism with a simple movement of the jaw on the basis of using SOLIDWORKS modelling tools. Empirical equations are obtained, which relate the parameters of the crusher: the height and thickness of the fixed and movable jaws and connecting rod, the length of the spacer plates from the size of the loading inlet, the size of the eccentricity from the stroke of the jaw. It is recommended to use the received regularities at designing the domestic crushers with a simple movement of the jaw.

Key words: jaw crusher; jaw crusher mechanism with a simple jaw movement; eccentricity; movable jaw stroke.

В роботі вирішена актуальна наукова задача, яка полягає в обтрунтуванні алгоритму моделювання механізму щокової дробарки з простим рухом щоки на основі використання інструментів моделювання SOLIDWORKS. Отримано емпіричні рівняння, котрі пов'язують між собою параметри дробарки: висота і товщина нерухомої і рухомої щок $і$ шатуна, довжини розпірних плит від розміру завантажувального отвору, розмір ексиентриситету від ходу щяоки. Рекомендується використовувати отримані закономірності при проектуванні вітчизняних дробарок з простим рухом щоки.

Ключові слова: щзокова дробарка; механізм щзокові дробарки з простим рухом щэоки; ексиентриситет; хід рухомої щоки.

\section{Problem's Formulation}

Jaw crushers with a simple movement of the jaw are produced by factories $[1-4]$ : CJSC "Avtokompozyt" (trademark "Drobmash", Viksa), PJSC "Volgotsemmash" (Tolyatti), machinebuilding corporation "Uralmash" (Yekaterinburg). On the territory of Ukraine, only the production of jaw crushers with complex jaw movement is established, and jaw crushers are not produced. The analysis of the state of the issue shows that there is a fundamental difference in the designs of the same typical sizes of crushers. The sizes of an outlet (the size of the crushed material), the stroke of a movable jaw, the size of eccentricity, coordinates of fixed supports, overall dimensions differ. This suggests that there is no unification despite the presence of state standard (DEST).

\section{Analysis of recent research and publications}

The analysis of the literature shows that the magnitude of the stroke of the movable jaw is determined by different ratios. For example, in Bauman's book [2] the stroke of the movable jaw $s$ is determined by the ratio $s=(0.04 \ldots 0.065) B$; in Klushantsev [3] $s=(0.01 \ldots 0.03) B$; in Dunaiev [4] $s=(0.03 \ldots 0.035) B$. In addition, according to the recommendations of Klushantsev [3] the size of the eccentricity is approximately equal to the stroke of the movable jaw, while Bauman with the reference to the study VNDIdormash [2] which states that the stroke should be twice the size of the eccentricity.

In order to determine the basic geometric parameters of jaw crusher (height and thickness of fixed and movable jaws and connecting rod, the length of the spacer plates from the size of the loading inlet, the size of the eccentricity from the stroke of the jaw) it is necessary to solve an urgent scientific problem, namely, to substantiate the algorithm for modeling the mechanism of the jaw crusher with a simple movement of the jaw. 


\section{Formulation of the study purpose}

The purpose of this work is to create sound recommendations for the design of a jaw crusher with a simple movement of the jaw, to determine the geometric dimensions of the mechanism of the jaw crusher with a simple movement of the jaw.

\section{Presenting main material}

Using modern SOLIDWORKS modelling tools, we will determine the relationship between the size of the eccentricity and the links of the mechanism of jaw crushers with a simple movement of the jaw and the stroke of the movable jaw. As a basic design we accept crushers size 900Ч1200 [14].

Fig. 1 shows a cross section of a jaw crusher with a simple movement of the jaw, as well as its model. Here it is marked: fixed jaw I - is modelled by a rod hinged in nodes 1 and 2; movable jaw II - is represented by a T-shaped rod (O1-3-5-6), which is hinged in node O1; front spacer plate III is depicted in the form of a rod 6-7; rear spacer plate IV - is marked with rod 8-O3, hinged in node O3; connecting rod V - is presented in the form of a T-shaped rod (7-8-9-10); eccentric shaft VI - is modelled by a $10-\mathrm{O} 2$ rod, which is hinged in $\mathrm{O} 2$ node.

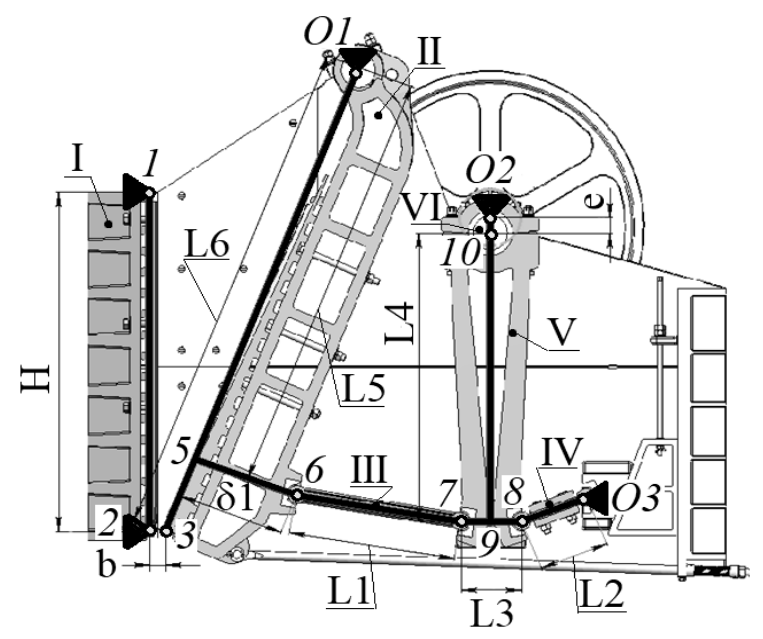

Fig. 1. Model of a jaw crusher with a simple movement of a jaw

To build the mechanism, we use the data given in literature [1-4], where it is known: the overall dimensions of the crusher; flywheel diameter; the stroke of the movable jaw $s=(0.03 \ldots 0.035)$ $B$; the size of the outlet $b$; the connecting rod and the eccentric must occupy a vertical position in the open state of the slot of the outlet. For the closed state it is known only that the connecting rod and the eccentric must be collinear; the angles of inclination of the spacer plates to the horizon should be $10 \mathrm{\epsilon}$; the width of the inlet $B$; the lower points on the fixed and movable jaws are horizontal. In order to fully determine the mechanism of JCS it is necessary in addition to the sizes $B, H, b, s, L 1, L 2, L 3, L 4$, $L 5, L 6$, д and д1 to determine the value of the eccentric $e$ coordinates of fixed supports $X O 1, Y O 1$, $\mathrm{XO2,} \mathrm{YO2}, \mathrm{XO}, \mathrm{YO} 3$.

Based on the above conditions, we construct a jaw crusher mechanism of the size 900Ч1200 according to the following algorithm [5]. Let's start with the open state of the mechanism. On the sketch we will create a rectangle which symbolizes the overall dimensions of the crusher. From data $[1-4]$ it is seen that the thicknesses of the fixed jaw and the rear support plate are equal and for this crusher are $600 \mathrm{~mm}$. This factor was taken into account when creating the sketch (Fig. 2). Here the overall dimensions of the crusher and the diameter of the flywheel are indicated by dash-dotted lines.

Construction of the open position of the crusher mechanism. From the origin of the coordinates we draw vertically down segment $1-2$ of length $H$. From point 2 to the right at a distance $\mathrm{b}$ we note point 3 , and from the origin of the coordinates at a distance $B-4$ (the size of the loading inlet $900 \mathrm{~mm}$ ). Through points 3 and 4 we construct a segment of length $L 6$ (without reaching a bounding rectangle). The position of the upper point of the segment $L 6$ corresponds to the position of the fixed 
support $O 1$. On segment 3-O1 from the point $O 1$ we draw $O 1-5$ of length $L 5$, and from the point 5 perpendicularly $O 1-5$ to the right we draw the segment 5-6 of length д1. From point 6 we construct a segment 6-7 at an angle to the horizon $15-16^{\circ}$ of length $L 1$. From point 7 we draw a horizontal line 7-8 of length $L 3$. From the centre of segment 7-8 (point 9) we draw perpendicularly upwards the segment 9-10 of length $L 4$. From point 8 at an angle to horizon $15-16^{\circ}-$ segment $8-O 3$ of length $L 2$. The position of the right point of segment 8-O3 corresponds to the position of the fixed support $O 3$. From point 10 collinearly upwards we draw a line 10-O2 without setting a size of length approximately equal to $b$.

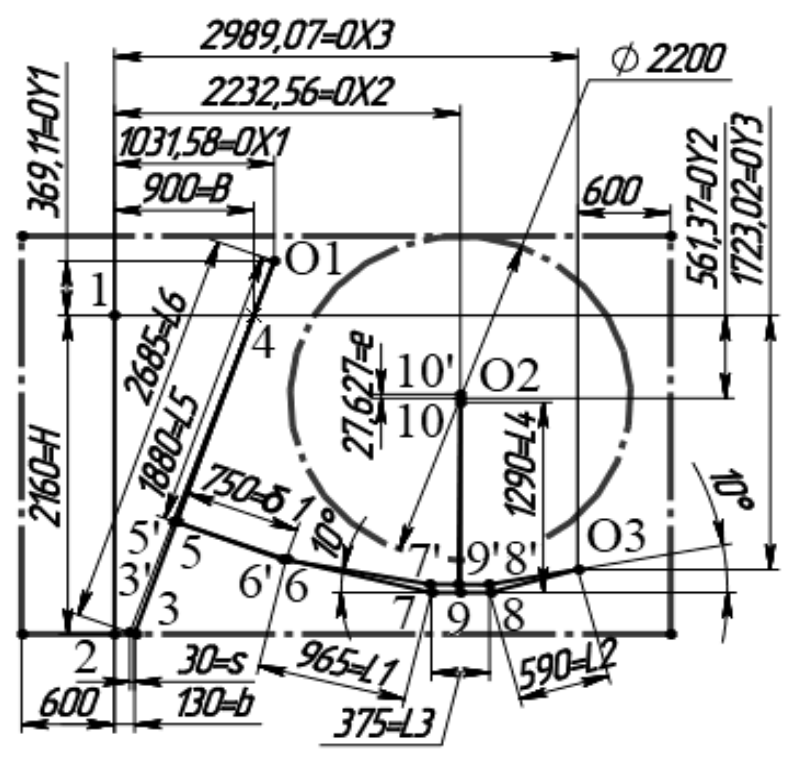

Fig 2. The mechanism of the crusher sizes 90041200

The jaw crusher mechanism with a simple jaw movement with the minimum outlet. From point $O 1$ we draw line $O 1-3$ and set the relationship "equality" between it and segment $O 1-3$, as well as the distance between the fixed plate and point $3^{\prime}-b_{0}=b-s$. Collinearly to segment $O 1-3$ we draw line $O 1-5$ and set the relationship "equality" to segment $O 1-5$. Next, draw a perpendicular 5-6 equal to 5-6. From the perpendicular at an arbitrary angle, we draw three interconnected lines 6'-7', $7^{\prime}-8$ ' and 8'-O3 and close them at point $O 3$. We add the relationship "equality" with 6-7, 7-8 and 8$O 3$. We check the angle of the spacer plates. To do this, we put a controlled angular size between the plates and the horizontal segment $7-8$. The angles should not exceed $10-12^{\circ}$. From the middle point of segment 7'-8' we lay up perpendicular 9'-10' with the relationship "equality" to segment 9-10. We connect perpendicular 9'-10' with eccentric 10-O2 obtained in the sketch with the outlet. Add the relationship "collinearly" (between 10'-O2 and 9'-10') and "equality" (between 10-O2 and 10'-O2). Both sketches became quite definite (black). Let's put "controlled": the size of the eccentric and the horizontal and vertical distances between the origin of the coordinates and the centres of the fixed supports $O 1, O 2$ and $O 3$.

Thus, for the given output data (sizes of the inlet and outlet, the stroke of the jaw), an algorithm for constructing the mechanism of the size 90041200 jaw crusher was developed, due to which the lengths of the mechanism links and coordinates of fixed supports were found.

Similarly, we will build mechanisms for crushers sizes 120041500,150042100 . The simulation results are presented in Fig. 3.

The analysis of mechanisms (Fig. 3) has made it possible to reveal the relationships between the geometric dimensions of the links and formulate the formulas to determine their value. In the formulas, all geometric parameters are expressed through the size of the loading inlet $B$ :

$$
\begin{gathered}
H=2.40 \cdot B, \\
L 1=1.072 \cdot B,
\end{gathered}
$$




$$
\begin{aligned}
L 2 & =0.656 \cdot B, \\
L 3 & =0.417 \cdot B, \\
L 4 & =1.433 \cdot B, \\
L 5 & =2.089 \cdot B, \\
L 6 & =2.983 \cdot B, \\
\delta 1 & =0.833 \cdot B .
\end{aligned}
$$

Next, determine the dependence of the size of the eccentricity on the stroke of the movable jaw of the crusher. For this purpose, the value of the eccentricity value in the range from $1 \mathrm{~mm}$ to $100 \mathrm{~mm}$ was changed on the constructed models (Fig. 2-3) and the value of the jaw stroke was measured.

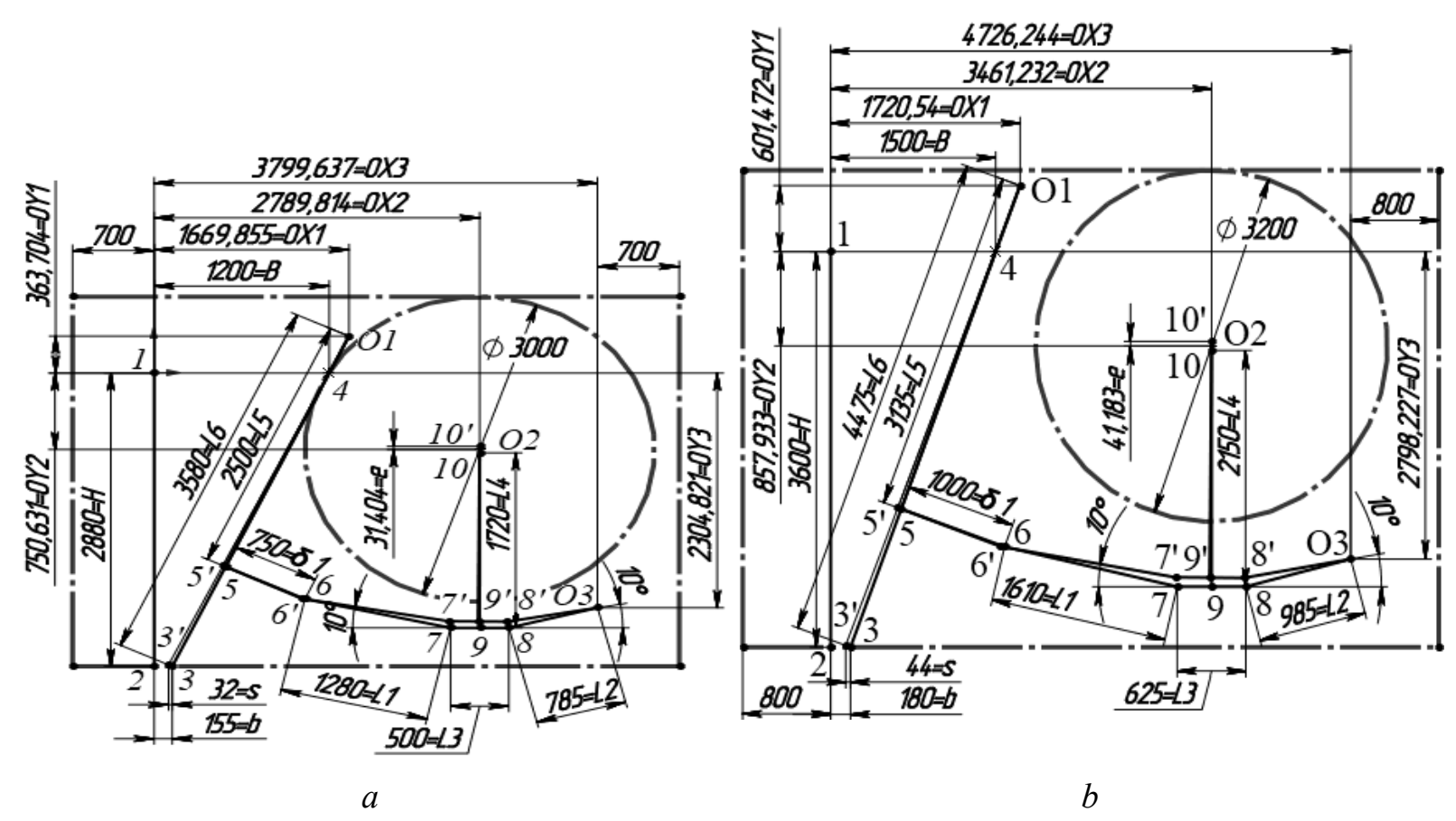

Fig. 3. The mechanism of the crusher: $a$ - for crushers sizes $120041500 ; b$ - for crushers sizes 1500 Ч 2100

Based on the results of the study, we construct a graph of the dependence of the value of eccentricity on the stroke of the movable jaw (Fig. 4). After analysing these graphs of dependence, we obtain approximation polynomials of the influence of the value of eccentricity on the stroke of the movable jaw of the form:

$$
\begin{array}{ll}
\text { - for crushers sizes } 900 Ч 1200 & e(s)=1.081 \cdot s+0.076, \\
\text { - for crushers sizes } 1200 Ч 1500 & e(s)=1.064 \cdot s+0.055, \\
\text { - for crushers sizes } 1500 Ч 2100 & e(s)=1.021 \cdot s+0.051
\end{array}
$$

\section{Conclusions}

The analysis of the literature shows that there is no unambiguous information on the choice of the parameters of the jaw crusher mechanism with a simple movement of the jaw that affect the kinematics of the movable jaw.

The actual scientific problem has been solved in the work, which consists in substantiation of the algorithm of construction of jaw crusher mechanism with a simple jaw movement on the basis of the use of the tools of SOLIDWORKS modelling. 
Empirical equations have been obtained which relate the parameters of the crusher: the height and thickness of the fixed and movable jaws and connecting rod, the length of the spacer plates from the size of the loading inlet, the size of the eccentricity from the stroke of the jaw.

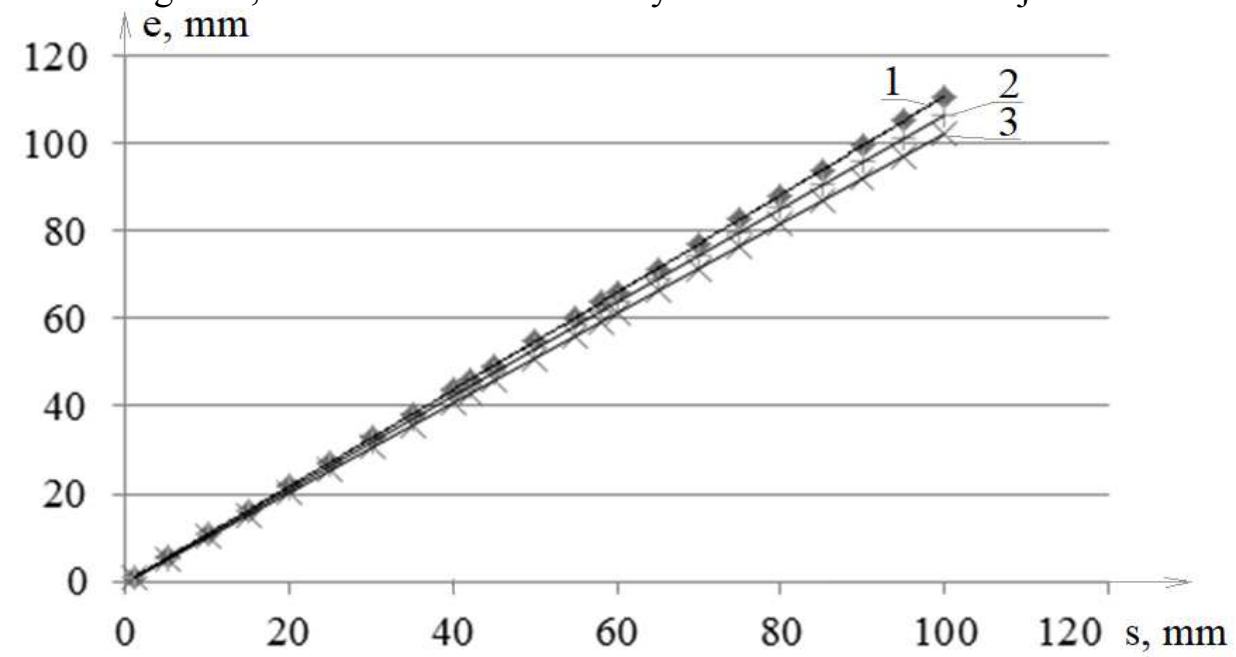

Fig. 4. The dependence of the magnitude of the eccentricity on the stroke of the movable jaw for different typical sizes of crushers

It is recommended to use the received regularities at designing domestic crushers with a simple movement of the jaw.

\section{References}

[1] Olevskii, V.A. (1963). Razmolnoye oborudovaniye obogatitelnykh fabrik [Grinding equipment of preparation plants. Reference manual]. - Moskva: Gosudarstvennoye nauchno-tekhnicheskoye izdatelstvo literatury po gornomu delu [in Russia]

[2] Bauman, V.A., Klushantsev, B.V. \& Martynov, V.D. (1981). Mekhanicheskiye oborudovaniye predpriyatiy stroitelnykh materialov, izdeliy i konstruktsiy [Mechanical equipment of enterprises of construction materials, products and structures]. Moskva: Mashinostroyeniye [in Russia]

[3] Klushantsev, B.V., Kosarev, A.I. \& Muizemnek, Iu.A. (1990). Drobilki. Konstruktsiya, raschet, osobennosti ekspluatatsii [Crushers. Construction, calculation, features of operation]. Moskva: Mashinostroyeniye [in Russia]

[4] Donchenko, A.S. \& Donchenko, V.A. (1986). Spravochnik mekhanika rudoobogatitelnoy fabriki [Handbook of mechanics of the ore processing plant]. Moskva: Nedra [in Russia]

[5] Mankovska, Ye.O. \& Panchenko, O.V. (2018). Obgruntuvannya parametriv pryvodu shchokovoyi drobarky z prostym rukhom shchoky. [Substantiation of the parameters of the drive of the jaw crusher with a simple movement of the jaw]. Molod': nauka ta innovatsiyi: Materialy VI Vseukr. nauk.-tekhn. konf. studentiv, aspirantiv i molodykh vchenykh, 15-16 lystopada 2018r. - Youth: science and innovation: materials of VI All-Ukrainian scientific and technical conference of students, graduate students and young scientists. 15-16 november 2018y. (pp. 2 -3). Dnipro: NTU "DP" [in Ukrainian] 


\section{ОБГРУНТУВАННЯ АЛГОРИТМУ МОДЕЛЮВАННЯ МЕХАНІЗМУ ЩОКОВОЇ ДРОБАРКИ 3 ПРОСТИМ РУХОМ ЩОКИ Панченко О.В.}

\section{Реферат}

В роботі вирішена актуальна наукова задача, яка полягає в обгрунтуванні алгоритму моделювання механізму щокової дробарки з простим рухом щоки на основі використання інструментів моделювання SOLIDWORKS.

Метою роботи $є$ створення обгрунтованих рекомендацій щодо проектування щокової дробарки з простим рухом щоки, визначення геометричних розмірів механізму щокової дробарки з простим рухом щоки.

Для визначення основних геометричних параметрів ЩДП (висота і товщина нерухомої і рухомої щок і шатуна, довжини розпірних плит від розміру завантажувального отвору, розмір ексцентриситету від ходу щоки) потрібно вирішити актуальну наукову задачу, а саме обгрунтувати алгоритм моделювання механізму щокової дробарки з простим рухом щоки.

Отримано емпіричні рівняння, котрі пов'язують між собою параметри дробарки: висота і товщина нерухомої і рухомої щок і шатуна, довжини розпірних плит від розміру завантажувального отвору, розмір ексцентриситету від ходу щоки.

Отримані закономірності, що пов'язують розмір ексцентрика 3 ходом рухомої щоки, а також геометричні розміри ланок механізму дробарки, перспективно використовувати при проектуванні вітчизняних дробарок з простим рухом щоки.

\section{Література}

1. Олевский В. А. Размольное оборудование обогатительных фабрик. Справочное пособие. Москва : Государственное научно-техническое издательство литературы по горному делу. 1963. $447 \mathrm{c}$.

2. Бауман В. А., Клушанцев Б. В., Мартынов В. Д. Механические оборудование предприятий строительных материалов, изделий и конструкций: Учебник для строительный вузов. 2-е изд., перераб. Москва : Машиностроение, 1981. 324 с.

3. Клушанцев Б. В., Косарев А. И., Муйземнек Ю. А. Дробилки. Конструкция, расчет, особенности эксплуатации. - Москва : Машиностроение, 1990. 320 с.

4. Донченко А. С., Донченко В. А. Справочник механика рудообогатительной фабрики. 2-е изд., перераб. и доп. Москва : Недра, 1986. 543 с.

5. Маньковська Є. О., Панченко О. В. Обгрунтування параметрів приводу щокової дробарки 3 простим рухом щоки. Молодь: наука та інноващї: матеріали VI Всеукр. наук.-техн. конф. студентів, аспірантів і молодих вчених (м. Дніпро, 15-16 листопада 2018 року). - Дніпро, 2018. C. 2-3. 